УДК 616-08-039.73

\title{
АПТАМЕРЫ В МЕДИЦИНЕ
}

\section{Ваганов Анатолий Анатольевич} аспирант кафедры педиатрии ИПО

Рубцова Светлана Олеговна ординатор кафедры педиатрии ИПО ФГБОУ ВО КрасГМУ им. проф. В.Ф.Войно-Ясенецкого Минздрава России Богатырева Анна Витальевна ординатор ФГБНУ ФИЦ КНЦ СО РАН Научно-исследовательский институт медицинских проблем Севера Научный руководитель: Таранушенко Татьяна Евгеньевна д.м.н. профессор, зав.кафедрой педиатрии ИПО ФГБОУ ВО КрасГМУ им. проф. В.Ф.Войно-Ясенецкого Минздрава России

Аннотация: в данной работе приведен литературный обзор о современном состоянии проблемы разработки и применения аптамеров в мировой медицинской науке и клинической практике с диагностической целью и в качестве терапии при различных нозологиях.

Ключевые слова: аптамер, диагностика, лечение, ПЦР, онкология, сахарный диабет, гемостаз.

\section{APTAMERS IN MEDICINE}

\section{Vaganov Anatolii Anatolevich Rubtsova Svetlana Olegovna Bogatyreva Anna Vitalievna Scientific supervisor: Tatyana Taranushenko Evgen'evna}

\begin{abstract}
: this paper presents a literary review of the current state of the problem of the development and application of aptamers in world medical science and clinical practice for diagnostic purposes and as a therapy for various nosologies.
\end{abstract}


Key words: aptamer, diagnosis, treatment, PCR, oncology, diabetes, hemostasis

Аптамеры - одноцепочечные олигонуклеотиды ДНК или РНК, которые могут связываться с различными мишенями: от различных ионов и небольших органических соединений до крупных белков и живых клеток [1, с. 22; 2, с. 80; 3 c. 2142]. Обладая специфической и стабильной трехмерной формой как в условиях in vitro, так и in vivo, аптамеры способны распознавать свои мишени с высокой аффинностью связывания и селективностью, поэтому их называют «химическими антителами» $[4$, с. 2$]$.

Аптамеры выбираются из больших библиотек случайных олигонуклеотидов, которые могут содержать до $10^{\wedge} 15$ уникальных последовательностей. Процесс отбора аптамеров, получивший название «Систематическая эволюция лигандов путем экспоненциального обогащения» (SELEX), был впервые разработан в 1990 году.

Технология SELEX - это процесс, который начинается с создания рандомизированной библиотеки олигонуклеотидов, инкубируемых с целевой молекулой, с последующим отбором по аффинности и этапы ПЦРамплификации для выявления и накопления последовательностей с самым высоким сродством.

Применение аптамеров показало, что антитела не являются единственными объектами, которые могут быть разработаны для связывания с мишенями с высокой аффинностью и специфичностью. Аптамеры обладают преимуществами в сравнении с антителами [5, с. 4016; 6, с. 129]:

- могут быть получены с использованием бесклеточного химического синтеза и, следовательно, менее дороги в производстве в масштабе;

- простота выполнения контролируемой модификации;

- высокая гибкость структуры;

- минимально иммуногенны;

- небольшой размер молекулы.

В связи с этим на данный момент имеются методы для открытия и создания новых кандидатов-мишеней для медицинских исследований (фундаментальные исследования, диагностика и терапия).

Пегаптаниб - первый терапевтический аптамер, одобренный FDA США в 2004 году в качестве антиангиогенного препарата для лечения неоваскулярной возрастной дегенерации желтого пятна. Данный препарат представляет собой 
пегилированный аптамер РНК из 27 нуклеотидов, который специфически связывается с преобладающей изоформой фактора роста эндотелия сосудов, блокирует его взаимодействие с родственным рецептором и в конечном итоге останавливает рост внутриглазных кровеносных сосудов.

Аптамер AS1411 представляет собой богатый гуанином олигонуклеотид из 26 оснований с немодифицированным (фосфодиэфирным) остовом ДНК. Данная молекула прошла клиническую оценку в отношении острого миелоидного лейкоза (ОМЛ), почечно-клеточной карциномы и запущенных солидных опухолей и показал многообещающие результаты, не вызывая серьезных побочных эффектов, но исследование на данный момент не принесло значимых клинических результатов [5, с. 4019].

NOX-E36 представляет собой пегилированный аптамер РНК, который имеет длину 40 нуклеотидов и связывается с высоким сродством с человеческим хемокином CCL2, также называемым MCP-1. CCL2 / MCP-1 один из ключевых хемокинов, который играет решающую роль в инфильтрации и позиционировании моноцитов. Сверхэкспрессия CCL2 и его рецептора CCR2 связана с множеством воспалительных заболеваний, что делает CCL2 интересной терапевтической мишенью [5, с. 4020]. Сильному связыванию NOX-E36 с CCL2 способствует медленная скорость, что приводит к высокой стабильности комплекса, что делает блокирование функции CCL2 еще более эффективным. NOX-E36 успешно завершил клиническое исследование фазы второй фазы у пациентов с диабетом 2 типа.

ARC1779 представляет собой 49-нуклеотидный аптамер, который конъюгирован с фрагментом полиэтиленгликоля массой 20 кДа и специфически связывается с доменом А1 фактора фон Виллебранда (ФВ) [7, с. 739]. ФВ - это гликопротеин, который играет ключевую роль в адгезии тромбоцитов, активации и стимулировании тромбоза [8, с. 42].

Связываясь с активированным ФВ, аптамер ARC1779 предотвращает взаимодействие A1-домена ФВ с рецептором GPIb тромбоцитов и блокирует путь активации, опосредованный ФВ, что приводит к потенциальному ингибированию активации тромбоцитов и патологическому тромбозу [5, с. 4021]. Рандомизированное плацебо-контролируемое исследование проходмло без явных побочных эффектов, и препарат демонстрировал зависимое от дозы и концентрации ингибирование активности ФВ и функции тромбоцитов, но дальнейшее изучение было остановлено по инициативе спонсора по финансовым соображениям [7, с. 739]. 
На данный момент ведутся работы и разрабатываются новые мишени для применения аптамеров с диагностической и терапевтической целями.

\section{Список литературы}

1. Nakamura Y. Aptamers as therapeutic middle molecules //Biochimie. 2018. - T. 145. - C. 22-33.

2. Morita Y. et al. Aptamer therapeutics in cancer: Current and future // Cancers. - 2018. - T. 10. - №. 3. - C. 80.

3. Zhuo Z. et al. Recent advances in SELEX technology and aptamer applications in biomedicine //International journal of molecular sciences. - 2017. T. 18. - №. 10. - C. 2142.

4. Kalra P., Dhiman A., Cho W.C., Bruno J.G., Sharma T.K. Simple methods and rational design for enhancing aptamer sensitivity and specificity. Front Mol Biosci. 2018; 5: 1-16

5. Kaur H. et al. Aptamers in the therapeutics and diagnostics pipelines // Theranostics. - 2018. - T. 8. - №. 15. - C. 4016-4032.

6. Rozenblum G. T. et al. Aptamers: current challenges and future prospects // Expert opinion on drug discovery. - 2016. - T. 11. - №. 2. - C. 127-135.

7. Галстян Г. М. и др. Лечение приобретенной тромботической тромбоцитопенической пурпуры //Терапевтический архив. - 2021. - Т. 93. № 6. - С. 736-745.

8. Бакунович А. В., Буланова К. Я., Лобанок Л. М. Молекулярные механизмы агрегации тромбоцитов //Журнал Белорусского государственного университета. Экология. - 2017. - №. 4. - С. 40-51.

(C) А.А. Ваганов, С.О. Рубцова, А.В. Богатырева, 2021 